

MARIAN FĄKA

\title{
Dzieje okupacyjne Kapituly Metropolitalnej w Poznaniu
}

W ramach wyniszczania narodu polskiego i politycznego oczyszczania gruntu w latach drugiej wojny światowej, hitlerowskie władze okupacyjne na pierwszym miejscu stawiały likwidację polskiej inteligencji i form organizacyjnych Kościoła katolickiego. Archidiecezja Poznańska znalazła się w całości w Okręgu Kraju Warty (Reichsgau Wartheland). Akcja władz hitlerowskich była w głównej mierze rozrachunkiem za działalność polityczną i społeczno-kulturalną oraz za patriotyczną postawę w okresie zaborów i międzywojennego dwudziestolecia.

Poniżej przedstawiamy dzieje okupacyjne Kapituły Metropolitalnej w Poznaniu, jak zostały nakreślone w Protokólarzu tejże Kapituły za lata 1935-1966 przez Ks. infułata Franciszka Rucińskiego-Nagórnego, ówczesnego dziekana i prałata kustosza Kapituly.

Ks. Franciszek Ruciński-Nagórny (1877-1946), po święceniach kapłańskich (1904) był wikariuszem przy kościele parafialnym Świętej Trójcy w Gnieźnie, od 1906 w Poznaniu przy kościele parafialnym św. Marcina, od 1911 penitencjarz przy katedrze poznańskiej. W roku 1918 został proboszczem parafii Najświętszego Serca Jezusowego i św. Floriana w Poznaniu, pehnił też funkcję sędziego prosynodalnego. W roku 1921 został przeniesiony do pracy w Konsystorzu Arcybiskupim i Ordynariacie. Od 1930 infułat kustosz, od 1938 infułat dziekan Kapituly Katedralnej w Poznaniu.

Tekst poniższy został tu dokładnie odtworzony z rękopisu zamieszczonego w wymienionym Protokolarzu, z zachowaniem starej pisowni i interpunkcji. Dodano też pięć stron fotokopii z tego rękopisu: cztery strony rejestrujące sześć posiedzeń kapitulnych w przeddzień i w pierwszych tygodniach okupacji (jedno z 20 sierpnia 1939 pozostałe z 13, 17, 18 września, 2, 30 października 1939) oraz stronę tytułową rękopisu. 
Foto 


\section{Foto}


Foto 


\section{Foto}




\section{Foto}


Dawno już zamierzony plan swój podbicia Europy pod hegemonia niemieckq rozpoczal Kanclerz $i$ wódz tzw. III-ciej Rzeszy niemieckiej Adolf Hitler (z nazwiska rodzicielskiego Schickelgruber) wprowadzać w czyn atakiem na Rzeczpospolita Polska. Dnia 1-go września $1939 r-w$ pierwszy piatek miesiaca - o godz. 5-tej wkroczyly znakomicie uzbrojone i wyposażone we wszelki nowoczesny sprzęt wojenny (- czolgi pancerne, pociagi pancerne, latawce bombowce $i$ t.p.-) armie niemieckie na terytorium polskie $w$ kilku miejscach jednocześnie. A o tymże czasie zawitaly nad Poznaniem pierwsze nieprzyjacielskie bombowce, zrzucajac na miasto kilkanaście bomb druzgodzacych. Wyspa tumska została szczęśliwie zachowana od wrogiego nalotu, najbliższa bowiem bomba padta na ulicy Wenecjańskiej, burzą fasade piętrowej kamienicy. Nastapiło jeszcze kilka dalszych nalotów nieprzyjacielskich, które w mieście poczynity szkody.

Już poprzednio dat Sztab glówny wojsk polskich Ks. Kardynatowi Prymasowi - Augustowi Hlondowi - znać smutna i bolesna wiadomość, że ze względów strategicznych Wielkopolska nie będzie broniona, lecz wydana będzie na okupację.

Pierwsze dni września minęly w Poznaniu spokojnie, tylko wszelkie wladze państwowe, urzędy samorzadowe i.i. opuszczaly poszpiesznie miasto, udajac się na wschód. W nocy na 3-go września opuścit pod naciskiem pana Prezydenta Rzeczpospolitej i Sztabu Glównego swa rezydencję Ks. Kardynal wraz z Kapelanem Ks. Dr. Bolestawem Filipiakiem i sekretarzem osobistym Ks. Dr Antonim Baraniakiem, salezjaninem, zdazajac do Warszawy. J. Eminencja zabrat ze soba tylko najkonieczniejsze przybory i akta, mianujac zastepca swoim z wszelkimi prawami ordynariusza Ks. Biskupa Walentego Dymka, sufragana $i$ wikariusza generalnego Poznańskiego. Wrazie jego śmierci lub uwięzienia miata wladza ta przejść na Ks. infutata Franciszka RucińskiegoNagórnego, a dalej dla tychże powodów na Ks. Kanonika Franciszka Jedwabskiego. Później, już z Rzymu, dodatkowo jeszcze przekazal Eminencja te władze z tymi samymi określeniami Ks. Kanonikowi Kolegiackiemu Dr Stefanowi Zwolskiemu oraz Ks. Dr Kornelemu Wierzbickiemu.

Wojska niemieckie wkroczyły do Poznania dnia 12 września, zaprowadzajac rygor wojenny a dla Polaków wrogi - a później zalały miasto i kraj władze niemieckie cywilne, szczególnie osławiona policja i t. zw. „Gestapo” t.j. Geheime Staats Polizei, z iście barbarzyńska wścieklościa i brutalnościa znęcajac się nad ludnościa polskq i katolicka.

Wybuch wojny zastat Kapitułę Metropolitalna Poznańskq w petnym składzie, a mianowicie byli następujacy członkowie:

1. Ks. Walenty Dymek, biskup Madyteński i wikariusz generalny - prepozyt, 
2. Ks. Franciszek Ksawery Rucinski-Nagórny, prałat-infułat-dziekan, radca Kurii Arcybiskupiej,

3. Ks. Józef Pradzyński, prałat-infulat-kustosz, prałat domowy J. Św.,

4. Ks. Kanonik Dr. Albert Steuer,

5. Ks. Kanonik Dr. Józef Paech, prokurator Kapituly,

6. Ks. Kanonik Henryk Zborowski, szef Kancelarii Prymasa, penitencjarz większy,

7. Ks. Kanonik Edward Hrabia O'Rourke, byty biskup w Rydze, później bp. tyt. kaneński, bp. tyt. pergameński, ostatnio bp. ordynariusz Gdański,

8. Ks. Kanonik Kaźmierz Szreybrowski, proboszcz parafii archikatedralnej,

9. Ks. Kanonik Dr. Nikodem Mędlewski, tajny szambelan J. Św., referent Kurii Arcybiskupiej, Kaznodzieja Kapitulny,

10. Ks. Kanonik Franciszek Salezy Jedwabski, notariusz Kurii Arcybiskupiej. Kanonikami Honorowymi byli:

1. Ks. Stanistaw Janasik, Dr prawa kan., Pratat domowy J. Św., Audytor Trybunatu Św. Roty Rzymskiej, Rektor Kościola św. Stanisława w Rzymie,

2. Ks. Jan Piotrowicz, radca duch., proboszcz w Skalmierzycach,

3. Ks. Kazimierz Karlowski, Dr. św. teol., Oficjat Metrop. Sadu Duch., Prof Sem. Duch.

4. Ks. Szambelan Stanisław Hutten-Czapski, Dr. św. teol.,

5. Ks. Radca Narcyz Putz, proboszcz św. Wojciecha w Poznaniu,

6. Ks. Dziekan Ludwik Rochalski, proboszcz w Macznikach.

Kler archikatedralny sktadat się z nastepujacych Kaptanów:

I. Penitencjarzy i kaznodziejów:

1. Ks. Kaźmierz Schmelzer, notariusz Metrop. Sadu Duch.,

2. Ks. Gerard Mizgalski, kustosz Archiwum i Muzeum archidiecezjalnego, preceator archikatedralny,

II. Kolegium wikariuszów:

1. Ks. Waclaw Stefaniak, Magister prawa świeck., wicedziekan,

2. Ks. Marian Magnuszewski, Kapelan Ks. Bpa, sekretarz Kurii Arcyb.,

3. Ks. Czesław Pawlaczyk, wicekustosz archikat.

4. Ks. Wackaw Walkowiak.

Dyrektorem chóru byl Ks. Wackaw Gieburowski, dr. fil. i muzykologii, szamb. J. Św., Kan. kon. Kapituly Katedr. Prenestyneńskiej, Prof Zw. Sem. Duch., Docent Uniwersytetu Poznańskiego. 
Organista Kościola Metropolitalnego byl Józef Pawlak.

Nieobecnym z czlonków Kapituly z powodu wyjazdu byl jedynie Ks. Bp. O'Rourke.

Tejże samej nocy co Ks. Kardynat - Prymas opuścit także Poznań Ks. Kan. Mędlewski, przestrzeżony, że okupacyjne władze niemieckie skazałyby go niezwłocznie na śmierć. Chorymi byli podówczas Ks. Kustosz Prądzyński (w domu) oraz Ks. Kan. Szreybrowski w Sanatorium SS. Elżbietanek w Poznaniu.

Pod względem narodowościowym byli wszyscy Polakami za wyjatkiem dwóch Niemców: Ks. Steuera i Ks. Paecha.

Nastaty dla Kapituly Metropolitalnej, Kościola Katolickiego i duchowieństwa polskiego dni ciężkiego prześladowania petne niepewności i obaw o przyszłość Kościola. Tymczasem opuszczajace terytorium wojska polskie wysadzity w powietrze mosty: Chwaliszewski, Chrobrego, Sródecki, mosty kolejowe nad Warta, Kanatem tumskim, Cybinq. Pociqgnęlo to za sobq wielkie straty $w$ wybitych szybach $w$ poszczególnych Kuriach oraz w Kościele metropolitalnym. Szkody te zdażyła Kapituła choć prowizorycznie natychmiast naprawić.

Niebawem wojska niemieckie okupowaty Poznań (12.9) i cała Wielkopolske, wlaczajac jq oraz inne terytoria Rzeczypospolitej pod nazwa ,, Warthegau" jako integralna część do Rzeszy niemieckiej.

Smutnym objawem niesolidarności Kaplańskiej byt fakt, że dwóch czlonków Kapituly Niemców, a mianowicie Ks. Steuer i Ks. Paech, wywiesili na domach swych choragwie Rzeszy niemieckiej ze swastyka hitlerowska. Ks. Paech thumaczyt się, ze uczynit to pod naciskiem, a Ks. Steuer zwlekat pewien czas z wywieszeniem choragwi. Ks. Kan. Paech posunqt swa nielojalność wobec Kapituly, Kościoła i społeczeństwa polskiego, wśród którego wyróst $i$ żyt $w$ dobrobycie $i$ spokoju do tego stopnia, iz odprawiajac $w$ Kościele OO. Franciszkanów, objętych już przez zakonników Niemców prowincji Bawarskiej dziękczynne nabożeństwo niemieckie z racji wkroczenia wojsk niemieckich do Poznania, dat upust swym wrogim uczuciom do Polaków, gdy w przemowie swej uroczystościowej »dziękowat Bogu za uwolnienie Niemców oraz Kraju tego z pod ucisku i prześladowania polskiego«!

Tymczasem nadciagnęty $i$ wladze cywilne niemieckie, a szczególnie ostawiona Tajna Policja Państwowa (Geheime Staatspolizel) i poczęly wydawać drakońskie rozporzqdzenia, kręujace coraz bardziej życie polskie i religijne Katolickie - oraz rozpoczynajac prześladowanie duchowieństwa $i$ wiernych. Przecież dziesiatki tysięcy Polaków w ciagu kilku miesięcy - pozbawiajac ich wszelkiego mienia - wywieziono badź to na zagładę do obozów koncentracyjnych badź to na laskę losu do Generalnego Gubernatorstwa. 
Wywożenia te odbywaty się w nocy - nieraz wśród straszliwego mrozu. Zabierano cale rodziny, dzieci, niemowlęta i starców z których setki całe $w$ drodze pomarty.

Dnia 3 października $1939 r$. zostat Ostrów tumski obstawiony przez po-

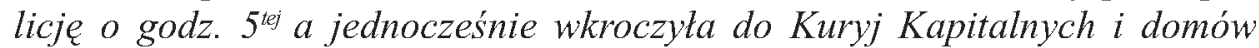
duchowieństwa archikatedralnego policja (G.S.P), by przeprowadzić rewizję rzekomo w poszukiwaniu broni i nielegalnych przedmiotów. W trakcie odbywania tejże rewizji odbywaty się przestuchy przez naczelników policji poszczególnych czlonków Kapituly, duchowieństwa archikatedralnego oraz personelu świeckiego, zamieszkujacego pałac prymasowski $i$ inne budynki Ostrowia Tumskiego. Głównym przedmiotem poszukiwań byly "tajne akta” prymasowskie, istniejace li tylko w bujnej fantazji przedstawicieli "policyjnego państwa niemieckiego". Rezultatem tych rewizyj (poza kradzieża różnych przedmiotów u poszczególnych Księży) byto uwięzienie Ks. Kanonika Zborowskiego, szefa Kancelarii Prymasowskiej, Ks. penit. Schmelzera, Ks. wik. Magnuszewskiego i Ks. wiceoficjała Dr Edmunda Nowickiego, których też natychmiast skierowano do więzienia przy ulicy Mtyńskiej.

Nabożeństwa w Kościele metropolitalnym odbywały się nadal, lecz coraz to nowe nakazywano ograniczenia. W wigilię Uroczystości Wszystkich Świętych (31. X. 1939) zawezwano do prezydium policji władze duchowna na konferencję. Ks. Bp. Dymek wydelegowat w swoim zastępstwie Ks. infulata Rucińskiego-Nagórnego i Ks. Msgr Dr. Teodora Taczaka, proboszcza Kościoła św. Marcina w Poznaniu. Na tejze konferencji obwieszczono zakaz śpiewania po kościołach pieśni patriotycznych, oraz surowe ograniczenie publicznych nabozeństw kościelnych ogólnie a w szczególności nabozienstw żalobnych $w$ dniu Wszystkich Swiętych $i$ w Dniu Zadusznym. Zarzadzenia te wydano 31. X.w poludnie, a miato obowiazywać od godz. 6-ej rano uroczystości Wszystkich Świętych.

Zamknięci $w$ więzieniu Kapłani przebywali tamze nadal bez jakichkolwiek przesluchów ze strony wladz okupacyjnych oraz widoków zwolnienia.

Dnia 7 listopada 1939 został uwięziony i przewieziony do więzienia na warowni Nr VII. Ks. Kanonik Kaźmierz Szreybrowski. Poczatkowo rnogła rodzina przekazywać mu bielizne i żywność. Atoli - wedhug późniejszych stwierdzeń czlonków jego rodziny - już 8 stycznia 1940 r. zakończyl tamże swe życie śmierciq gwaltownq. Jakkolwiek wladze policyjne twierdzily, ze zmart wskutek choroby $i$ stabości, gdyż "takiego surowego życia starsza i schorowana osoba nie jest $w$ stanie wytrzymać, to twierdzili wspótwięzieni, iż zmarl śmiercia męczeńska katowany i prześladowany za wiarę i polskość - ostatecznie rozstrzelany.

Na dzień 9 listopada 1939 zawezwato „Gestapo” caly szereg kaptanów miasta Poznania - a mianowicie Księży Dr. Stanisława Brossa - Tadeusza 
Gałdyńskiego - Dr Walerego Adamskiego - Dr. Edwarda Kozłowskiego Franciszka Rucińskiego-Nagórnego - Stefana Janiaka - Romana Mielińskiego - Franciszka Marlewskiego - Kaźmierza Michalskiego - Jana Czerniaka - Jana Krajewskiego - Józefa Jasińskiego - Dr. Teodora Taczaka Stanisława Matuszczaka - Stefana Kaczorowskiego - Dr. Jana Kicińskiego - Dr. Witolda Klimkiewicza - Ludwika Walkowiaka - Dr. Seweryna Kowalskiego - Czestawa Heyduckiego - Antoniego Banaszaka i innych - do »Domu Żolnierza« przy ul. Ratajczaka, gdzie mialo swoja glówna kwaterę, $i$ wywieziono ich, dołaczajac po drodze jeszcze uwięzionych $w$ więzieniu $i$ we warowni Główieńskiej: Księży Zborowskiego, Edmunda Nowickiego, Pawła Steinmetza, Wactawa Gieburowskiego, do Klasztoru Księży Rodziny Marii w Kaźmierzu Biskupim, $w$ diecezji Wtoclawskiej, gdzie ich internowano pod nadzorem tamtejszej policji niemieckiej. Trzech z wymienionych - a mianowicie Księży Steinmetza, Marlewskiego i Krajewskiego odtransportowano dalej jako zakładników do więzienia w mieście Koninie, z tym, że, o ile zajda w Klasztorze Kaźmierskim jakiekolwiek przekroczenia lub ucieczka, owi zakladnicy natychmiast zostana rozstrzelani. Los internowanych byt w Kaźmierzu znośny, musieli za utrzymanie oplacać zarzadowi zakonnemu, była możność odprawiania mszy św. poczatkowo dla każdego co 6-ty tydzień, później codziennie. W maju 1940 większość zostata wywieziona przez Poznań do obozów koncentracyjnych w Dachau, Mathausen i in. Kilku starszych (ponad 60 lat) dostała zezwolenie udania się do Generalnego Gubernatorstwa.

Dalszym czynem wladz okupacyjnych w Poznaniu byto internowanie Ks. biskupa Dymka w jego mieszkaniu, a które później zostało mu zabrane a on sam przesiedlony na wikariat przy Kościele Matki Boskiej Bolesnej na Łazarzu - oraz calkowita konfiskata nieruchomego i ruchomego majatku Kapituly Metropolitarnej jak wogóle calego majatku kościelnego w obu archidiecezjach a takze w całym $t$. zw. Warthegau. - Domy mieszkalne za wyjątkiem dwóch Kuryj, zamieszkatych przez Niemców Kanoników, zostaty przekazane na własność - zdaje się - gminy miasta Poznania.

Germanizacja i prześladowanie Kościoła Katolickiego postępowała szybko naprzód. Przyszło do zamknięcia Kościoła metropolitalnego i Kościota N. Marii P in Summo, jako i wszystkich innych Kościołów Poznańskich za wyjatkiem Kościola św. Wojciecha i M. Bosk. Bolesnej na Lazarzu oraz Kościoła OO. Franciszkanów oddanego niemieckim zakonnikom prowincji Bawarskiej. Wszelka wlasność Kościola metropolitarnego w szatach liturgicznych, aparatach, sprzęcie kościelnym - a także wlasność prywatna, która tamże dla bezpieczeństwa umieszczona została - została przez Niemców zrabowana. Losowi temu ulegla też historyczna porcelana palacu arcybiskupiego (talerze z herbami biskupstw, ziem i województw Rzeczypospolitej Polskiej). 
Archiwum Kapitulne dawne, umieszczone w Archiwum Archidiecezjalnym przy ul. Lubrańskiego l, zostało po zlikwidowaniu tegoż przez władze niemieckie w końcu września 1940 r. przewiezione do gmachu Archiwum Państwowego w Poznaniu (Góra Przemystawa 1) i bylo tam pod okiem dyrektora Archiwum Archidiecezjalnego Ks. prof Dr Józefa Nowackiego. Ocalało ono z wyjątkiem dawnych planów i map oraz części luźnych papierów, które splonęly w podpalonym przez wychodzacych Niemców z gmachu na Górze Przemystawa. Dyplomy pergaminowe i 3 kopiarze dokumentów wywieźli Niemcy poprzednio do kopalni soli Grosleben (za Magdeburgiem), dawne rękopisy $i$ akta do kościolów parafialnych w Ceradzu Kość. i Bytyniu. Rewindykacja ich jest w toku, uzależniona głównie od środków lokomocji.

Wobec zrabowania catego majatku kapitulnego, spalenia Katedry oraz braku duchowieństwa archikatedralnego ustaly z natury rzeczy wszelkie kapitulne chórowe nabożeństwa, aniwersarze $i$ duchowe obligi legatowe i fundacyjne. - Ostatnie wyplaty, jakie wykonat prokurator Ks. Paech, które dało się stwierdzić, dla czlonków Kapituly byly za marzec $1940 \mathrm{r}$. Zamiast pensji: bp. Dymek 21,26; Ks. Pradzyński 121,26; Ks. Jedwabski 121,26; oraz reszta z dzierżawy z Brodów/Podlesia na dniu l-go marca 1940 r: bp. Dymek, Ruciński, Pradzyński, Steuer, Paech, Zborowski, Jedwabski-kazdy po 191,06 RM. Odtad - o ile można wywnioskować z niekompletnych i tylko częściowo zachowanych akt - poborów $i$ wyplat majatku kapitulnego czlonkowie Kapituly nie pobierali.

Los poszczególnych czlonków Kapituly Metropolitalnej byl następujacy:

1. Ks. bp. Dymek zarzqdzat nadal archidiecezjq Poznańska w myśl pisma Kardynała - Prymasa z dnia 3 września 1939 r, poczqtkowo nad cała archidiecezja. Z chwilq utworzenia administracji apostolskiej (osobowej) dla Niemców - katolików w t. zw. Warthegau, tylko nad katolikami-Polakami archidiecezji. W styczniu 1943 zostat usunięty ze swego mieszkania i przesiedlony na mieszkanie w wikariacie przy Kościele Matki Boskiej Bolesnej w Poznaniu. Pierwotnie byt internowany w swym mieszkaniu, później zyskat możność swobodnego poruszania się. Caty czas okupacji niemieckiej przetrwat Ks. biskup mężnie $i$ bohatersko wśród najprzykrzejszych warunków pracy szarpiqcej nerwy - nie rokujacej pomyślniejszych rezultatów na przyszłość. - Nawiasem dodaje się, że administratorem apostolskim dla Niemców - katolików dla calego t. zw. Warthegau - a więc terytorium personalnego zostat mianowany poczatkowo Ks. Kan. Dr. Józef Paech, po jego rezygnacji spowodowanej choroba franciszkanin O. Breitinger, który petnit ten urzad $a \dot{z}$ do swej ucieczki przed wojskami rosyjskimi w styczniu $1945 \mathrm{r}$.

2. Ks. infulat Franciszek Ruciński-Nagórny wywieziony na dniu 9 listopada 1939 do Kaźmierza Biskupiego, przebywat tamże internowany aż do 
9 lipca 1940 poczem uzyskawszy od landrata w Koninie urlop zdrowotny do szpitala Sióstr Shuzebniczek w Pleszewie, przebywat tamże do 12 lutego 1941 $r$ Pobyt w Klasztorze Kaźmierskim, gdzie internowano czterdziestu kilku kaplanów, w tym dominikanów i franciszkanów poznańskich, byt znośny. Nadzór wykonywali z jednej strony rektor tamtejszego Zgromadzenia Misjonarzy od Św. Rodziny (Congregatio Missionariorum a S. Familia) - oraz miejscowa policja niemiecka. Ponadto przybywali od czasu do czasu ",gestapowcy", przywożac pocztę i paczki. Internowani kaplani placili Zgromadzeniu za swe utrzymanie. Na ogól panowata w obrębie zakladu zupelna swoboda. Pozwolono nawet po pewnym czasie na odbywanie przechadzek do lasu. $\mathrm{Na}$ początku roku 1940 poleciło Gestapo zgłaszać się do Generalnego Gubernatorstwa - a w kwietniu czy maju wywieziono większość (ponizej 60 lat) do Poznania do więzienia a później do Dachau. - Ks. Rucinski po podpisaniu w Pleszewie deklaracji o dobrowolnym przesiedleniu się /:,,dass er freiwillig auswandere"/ udat się do tak zwanego Gubernatorstwa Generalnego, gdzie osiadt przy Klasztorze SS. Urszulanek w Rokicinach (Powiat Nowotarskl) a po usunięciu tychże przez władze niemieckie z Klasztoru opodal w Chabówce, sprawujac nadal czynności duszpasterskie dla SS. Urszulanek, które w Rokicinach pozostaly. Dnia 28 sierpnia 1944 zamianowat go Ksiażę metropolita Sapieha pismem 3933/44 wobec nieobecności miejscowego proboszcza Ks. Józefa Polońskiego wikariuszem substytatem Kościoła parafialnego w Rabie Wyżnej (dekanatu Nowotarskiego), który to urzqd spetniał do polowy grudnia tegoż roku. W Chabówce przebywat Ks. $R$. do dnia 12 marca 1945 - a dnia 18 marca tegoż roku powrócil do Poznania, by objać zajmowane przed wojna stanowisko dziekana Kapituly.

3. Ks. infulat Józef Pradzyński przebywat jako chory w swej Kurii, później usunięto go z mieszkania stużbowego na probostwo św. Rocha, skąd przez "Gestapo" wywieziony zostal 3 maja 1941 r. do obozu koncentracyjnego w Dachau w Bawarii. Tamże jako wzorowy Kapłan - męczennik zakończyl swe życie 27 czerwca 1942 r. (w sobotę o godz. 16 1/2). Cialo jego zostało w barbarzyński sposób wedlug praktyki zwyrodnialych hitlerowców spalone.

4. Ks. Kanonik Dr. Albert Steuer pozostat w czasie catej niemieckiej okupacji na miejscu. Oddat dużo postug duchownych Polakom skazywanym na śmierć przez okupacyjne sady niemieckie. Krótko przed zdobyciem Poznania przez wojska rosyjskie uszedl z Poznania jako Niemiec - na rozkaz odnośnych wladz partyjnych niemieckich.

5. Ks. Kanonik Dr. Józef Paech, afiszujacy podpadajaco swoja narodowość niemiecka, zostal mianowany administratorem apostolskim dla katolików niemieckiej narodowości $w$ t. zw. Warthegau, później atoli zlożyl ten 
urzad dla słabego zdrowia. Zmark na paraliż dnia 8 grudnia 1943 r, pochowany $w$ mieście pochodzenia $w$ Pszczewie.

6. Ks. Kanonik Henryk Zborowski, uwięziony w Poznaniu dnia 3.10.1939 jako szef Kancelarii Prymasa Polski, przewieziony 9.11.1939 do Kaźmierza Biskupiego i tamże internowany, przenióst się ze względu na chorobe za zezwoleniem landrata $w$ Koninie do Sanatorium SS. Elzbietanek w Poznaniu, skad pod naciskiem władz policyjnych niemieckich po wyzdrowieniu udat się do Warszawy, gdzie znalazl przytulek u rezydujacego tamże - także wygnańca - biskupa Katowickiego, Ks. Stanistawa Adamskiego, Powrócit do Poznania na dniu 4 marca 1945 r. - Od 26 marca tegoż roku przebywa przejściowo na kapelanii SS. Urszulanek w Pokrzywnie, gdy jego Kuria częściowo zajęta przez żotnierzy rosyjskich.

7. Ks. Kanonika, biskupa Edward[a] hr O'Rourke zaskoczyła wojna na wywczasach wakacyjnych. Z Polski udat się droga okrężna przez Królewiec, Berlin do Rzymu. Tamże osiadl przy jakimś Klasztorze męskim. Zmart tamże 27 czerwca $1943 r$.

8. Ks. Kanonik Kaźmierz Szreybrowski - jak się już wyżej zaprotokólowato - zakończyt śmierciq męczeńska swe bogobojne życie $w$ warowni VII w Poznaniu dnia 8 stycznia $1940 \mathrm{r}$.

9. Ks. Kanonik Dr. Nikodem Mędlewski uszedl przed grożacym prześladowaniem niemieckim dnia 3 września 1939 r. $i$ udat się droga okrężna do Londynu, gdzie caly czas wojny - jak dochodzity pogtoski - przebywat. O ostatecznym losie jego $w$ chwili pisania niniejszego protokółu nic bliższego nie wiadomo.

10. Ks. Kanonik Franciszek Jedwabski do 5 października 1941 r. byt prawa ręka i pomoca Ks. Biskupowi oraz proboszczem parafii archikatedralnej. $W$ dniu tym zostat wraz z reszta księży $z$ archidiecezji wywieziony do obozu koncentracyjnego w Dachau, gdzie do chwili pisania niniejszego protokólu przebywa.

Los kanoników honorowych jest nastęujacy:

1. Ks. Dr Stanistaw Janasik, prałat domowy, audytor Trybunału Sw. Roty Rzymskiej i rektor Kościoła św. Stanistawa w Rzymie, zdolat pomimo wojny powrócić na swe stanowisko do Rzymu. Dnia 6 grudnia 1942 r. zmart tamże na udar serca. Po odprawionych uroczyście eksekwjach w Kościele św. Stanisława przez Ks. bkpa O'Rourke pochowany zostal w Rzymie na Campo Santo.

2. Ks. Jan Piotrowicz, proboszcz Skalmierzycki, przebyl czas okupacji tamże, eksmitowany atoli z probostwa.

3. Ks. oficjat Dr Kaźmierz Karlowski przebyl czas okupacji w Guberna- 
torstwie Generalnym. Powrócit do Poznania i jest nadal czynny jako oficjał Metropolitalnego Sadu Duchownego.

4. Ks. Dr. Stanistaw Hutten-Czapski przebyt czas okupacji w Modrzu wraz z bratem swym Józefem, wlaścicielem tegoż majątku, który - jak wszyscy inni - pozbawiony zostal przez wtadze okupacyjne własności swojej. Przebywa tam nadal jako rezydent.

5. Ks. Narcyz Putz, proboszcz św. Wojciecha w Poznaniu, wywieziony do Dachau, odznaczat się tamże niebywatym męstwem, krzepiac na duchu konfratrów $i$ innych wspótinternowanych więźniów. Dokonat męczeńskiego żywota na dniu 15 grudnia 1942 r.

6. Ks. dziekan Rochalski, proboszcz w Macznikach, zabrany przez „,Gestapo" dnia 5 października 1941 r. wraz z cala nieomal reszta duchowieństwa, przebywat przez dni kilka w warowni VII, gdzie zostat nieludzko skatowany. Przewieziony po tym na leczenie do sanatorium św. Elżbiety w Poznaniu, tamze po kilku dniach ducha wyzional.

Los duchowieństwa archikatedralnego był następujacy:

Po rewizji „Gestapo” dnia 3 października (od 4 rano do 13-ej), podczas której „gestapowcy" wykryli na poddaszu wikariatu kilka naboi myśliwskich, pozostałych z czasów Ks. Kaźmierskiego, oraz transparentów, używanych w pochodach ku czci Chrystusa Króla. Znieśli je na dót jako material obciażajacy, przez Komendanta atoli odrzucony. Zabrano podówczas Ks. Schmelzera i Ks. Magnuszewskiego do więzienia jako odpowiedzialnych: pierwszego za akta Sadu Duchownego drugiego za akta i kasę Kurii Arcybiskupiej. Przy końcu października tegoż roku (1939) zmuszono księży wikariuszów do opuszczenia wikariatu. Pozbawionych dachu nad glowa: Ks. Stefaniaka przygarnat Ks. Kan. Jedwabski, a księży Pawlaczyka i Walkowiaka Ks. Kan. Szreybrowski. Wikariat opuszczono dnia 31 października. - We wtorek, dnia 7 listopada 1939 około godziny 18-ej ,Gestapo” zabrało Ks. Kan. Szreybrowskiego z domu. W mieszkaniu jego pozostali nadal jeszcze na pewien czas obaj księża wikariusze.

W środe 8 listopada 1939 o godz. 22 wywieziono księży Pawlaczyka $i$ Walkowiaka do obozu na Glównej - a stamtad l grudnia do Generalnego Gubernatorstwa do Ostrówca Świętokrzyskiego w diecezji Sandomierskiej. Ks. Walkowiaka po kilku tygodniach pobytu w Ostrówcu skierowata Kuria Biskupia Sandomierska do parafii Szewna pod Ostrowcem jako rezydenta, a po 2 latach przeznaczyta na wikariusza w parafii Lasocin, powiat Opatów. Na tym stanowisku przetrwat do lutego $1945 \mathrm{r}$, w którym to miesiacu wrócit do Poznania i niebawem obją administracje parafii w Obornikach.

Ks. Czesław Pawlaczyk, skierowany po przybyciu do Ostrówca przez miejscowy komitet dla wysiedlonych do Opatowa, przebyl tam miesiac u Ks. 
dziekana, Kanonika Cieślakowskiego. Przekazany stamtad do pomocy w parafii przez Ks. prob. Stanisława Zbroje, spędził z nim jako gość - rezydent 2 lata w parafii Modliborzyce (pow. Opatów), a po przeniesieniu Ks. prob. Zbroi do Polańca jeden rok w Połańcu (pow. Sandomierz). Przez dwa ostatnie lata wojny mieszkat u rodziny swojej w Milanówku pod Warszawa, pomagajac miejscowym księżom w pracy duszpasterskiej $i$ szkolnictwie, a prócz tego od sierpnia 1944 r. zatrudniony byl jako kapelan szpitalny. Pod koniec lutego 1945 powrócit do Poznania i petnit do końca marca funkcje wikariusza parafii archikatedralnej. $Z$ dniem 1-go kwietnia objat urzad administratora tejze parafii.

Ks. Schmelzer z więzienia na Mtyńskiej przewieziony zostal 9 listopada 1939 z innymi księżmi do Kaźmierza Biskupiego i tam internowany. Zwolniony stamtad wskutek choroby nerwów, przebywat czas jakiś w Poznaniu później na rozkaz "Gestapo" wyjechat do Generalnego Gubernatorstwa. Dhuższy czas przebywat w Warszawie, a później w Skierniewicach. W pierwszej polowie marca 1945 powrócit do Poznania $i$ z polecenia Wladzy duchownej obją administracje parafii Rydzyna pod Lesznem.

Ks. Magnuszewski z więzienia na Mlyńskiej po przez internowanie w Kaźmierzu wywieziony został do Dachau, gdzie dotad przebywa.

Ten sam los spotkat księży Mizgalskiego i Stefaniaka - aresztowanych w r. $1940-i$ wywiezionych ostatecznie również do Dachau.

Ks. Dr Wackaw Gieburowski wywieziony do Kaźmierza Biskupiego, później zwolniony do Poznania, gdzie petnil czynności duszpasterskie, ostatecznie wydalony do Generalnego Gubernatorstwa przenióst się do Warszawy, gdzie po trzykrotnej operacji zmart dnia

Organista Józef Pawlak wywieziony zostal również do Dachau.

Caly obszar Ostrowia Tumskiego - zajęty na cele i mieszkania różnej kategorii policij niemieckich - przetrwat materialnie caly czas okupacji niezniszczony - poza doszczętnym obrabowaniu kościołów, pałacu arcybiskupiego, kuryj i domów kapitulnych przez Niemców z wszelkiego mienia. Zamknięte kościoly zostały przez barbarzyńskich najeźdzców niemieckich sprofanowane i zbeszczeszczone. W Katedrze obrabowanej takze z pięciu bronzowych płyt Vischerowskich (biskupa Ariela Górki, kanonika Bernarda Lubrańskiego, wojewody Łukasza Górki, biskupa Andrzeja Opalińskiego $i$ kanonika Grodzickiego) urzadzono sktad armat $i$ innego sprzętu wojennego, przeróżnych mebli grabowanych po palacach, eksponatów pozwożonych $z$ przeróżnych pałaców, kościołów i muzeów - podobnie postapiono z Kościolem Panny Marii in Summo oraz św. Matgorzaty. W tym ostatnim zdeponowano cale stosy (powyżej okien) ksiqżek pozabieranych z przeróżnych bibliotek prywatnych, uniwersyteckich i. tp. 
Tragicznym i stały się ostatnie dni pobytu Niemców w Poznaniu. Gdy miasto zdobyte zostato przez Rosjan już po lewym brzegu Warty, bronili sie Niemcy jeszcze na prawym brzegu, szczególnie na Ostrowiu tumskim. Stad poniosty ciężkie uszkodzenia kościoly i gmachy Ostrowia tumskiego. Kościót Metropolitalny zostal $w$ przeddzień kapitulacji t.j. $w$ czwartek 15 lutego o godz. 16,45 przez Niemców pociskami zapalajacymi podpalony. Splonęly wszystkie pięć wież, cała nawa główna, wszystkie sklepienia tak nawy głównej jako też kaplic. Oltarz glówny ocalat, spalone natomiast zostaly stale chórowe, chórki $w$ prezbiterium, jedne $i$ drugie organy, cate wnętrza wież $z$ wszystkimi dzwonami ulegly również pożarowi. Zachowaly się prawie nieuszkodzone kaplice boczne (szczególnie złota) i pomniki. Nawet groby arcybiskupie w podziemiach Kaplicy Szoldrskich zostały przez barbarzyńców niemieckich naruszone. Rozbito plyte kamienna, kryjacq wejście; otwierano trumny także bpa Andrzeja Szoldrskiego, stojaca w Kaplicy samej.

$W$ splondrowanych i rozbitych zakrystiach leżaly cate olbrzymie stosy puzder próżnych od kielichów mszalnych i monstrancyj. Wszelkie tak bogate paramenty kościelne zostały rozkradzione - skarbiec również spladrowany.

Na ogól wszelkie zabudowania duchowne wyspy stużyly za lokale stużbowe i koszary dla różnych gatunkowo policji niemieckiej.

Pałac arcybiskupi ograbiony i uszkodzony pociskami, podobnie gmach Kurii Arcybiskupiej.

Kuria nr. 3 (prepozytura) jest bardzo uszkodzona pociskami armatnimi. Dach $w$ większej części zrujnowany. Ściana piętra mocno uszkodzona przez pociski - wyrwy duże w dwóch miejscach.

Kuria nr. 4 i 5 zachowane bez większych uszkodzeń.

Domy $n r .5^{a}$ i 6 bardzo zrujnowane, dachy calkowicie strzaskane, niezdatne do zamieszkania.

Dom $n$ r 9 (historyczna i zabytkowa psatteria) uszkodzony $i$ zburzony może najwięcej - mianowicie strona zachodnia. Istnieje atoli możliwość uratowania go od ostatecznej zaglady.

Kuria nr. 10 bardzo mocno uszkodzona - mianowicie strzaskany caly dach.

Kuria nr. 11 (dziekania) również mocno uszkodzona, mianowicie dach, ściany i okno pietra i parteru oraz klatka schodowa pociskami armatnimi.

Kuria nr. 13 uszkodzony szczególnie dach i sufity.

Kuria nr. 14 bardzo uszkodzona, gdy pociski armatnie uderzyly wlaśnie $w$ ściane pomiędzy parterem a piętrem.

Remizy kapitalne i kuria nr. 11 i 15/16 mocno uszkodzone. 
Kuria $n r$ 15/16 i 17 uszkodzone niebardzo i zdatne do zamieszkania naturalnie po remoncie.

Kuria nr. 18 (Kustodia) uszkodzona - ale prowizorycznie naprawiona przez 4 Urząd Skarbowy, któremu dla jego urzędowania przekazano ubikacje parterowe.

Wikariat przy ul. Lubrańskiego 2 bardzo uszkodzony, budynek gospodarczy calkowicie spalony.

Organistówka (Lubrańskiego 5) i dom dyrektora chóru (Lubrańskiego 6) uszkodzone znacznie.

Dom przy ul. Lubrańskiego 7 bardzo mocno uszkodzony.

Co nie zniszczyla wojna i działania pocisków armatnich, to $w$ dalszym ciagu niszczyli żolnierze rosyjscy, tamiac i demolujac wszystko co wpadto w ich ręce - szczególnie darli i niszczyli wszelkie napotkane ksiażki. Niestety i ludność miejscowa polska pladrowata, niszczyla i okradala opuszczone domy, włamujac się do wnętrza pomimo zamknięcia przemoca.

Tak przedstawia się smutno stan budowlany kościołów i gmachów Kapituly Metropolitalnej - straszliwy obraz zdziczenia wojennego - demonicznej nienawiści Niemców - obraz rzekomej kultury XX-go wieku bez Boga i Jego przykazań. Z pewnościa przez przeszło dziewięć wieków istnienia Katedry i Kapituly nie doznaly one takiego spustoszenia - jak tego dokonanego ręka zdziczatego żolnierza niemieckiego. - Co całe wieki skrzętnej i kulturalnej pracy mozolnie budowaty, to legło $w$ gruzach zburzone zdziczeniem ,kultury" XX-go wieku. - W Bogu, który Stwórca i Panem wszechświata, nadzieja, że to co wroga i barbarzyńska ręka germańska i rosyjska zburzyła i zniszczyła - odbuduje mrówcza i celowa - a zbożna praca Kościoła i jego stug.

Jakkolwiek pożoga wojenna jeszcze nie zagasła, życie religijne $i$ shużba Boża rozpoczęla się $i$ na Ostrowiu Tumskim z Wielkim Czwartkiem (29 marca 1945 r) narazie nabożeństwami parafialnymi w Kościele Panny Marii in Summo.

Gdy atoli Kościót Metropolitalny czesściowo w gruzach i spalony, gdy Kapituła Metropolitalna w rozproszeniu (na Ostrowiu Tumskim przebywa tylko jeden - nizej podpisany) - pozbawiona wszelkiego majatku, nie ma na razie widoków i możliwości, by wskrzesić nabożeństwa chórowe katedralne, Msze konwentualne, aniwersarze i. tp. Trzeba będzie z tym poczekać aż do czasów, gdy materialnie i finansowo podniesiona zostanie Kapituła Metropolitalna do przedwojennego stanu.

Poznań, dnia l kwietnia $1945 r . \quad$ Ks. infulat Franciszek Ruciński-Nagórny sekretarz Kapituly 